\title{
Feasibility of Single-port Reversal of Left-sided Colostomy in the Presence of Incisional Hernia; Promising Results
}

\section{Kesi Fıtığı Varlığında Sol Taraflı Kolostominin Tek Portlu Tersine Çevrilmesinin Fizibilitesi; Umut Verici Sonuçlar}

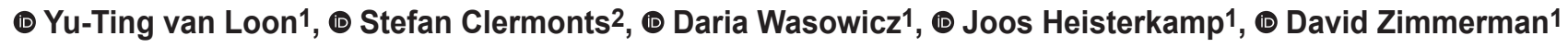 \\ ${ }^{1}$ Elisabeth-TweeSteden Hospital, Clinic of Surgery, Tilburg, Netherlands \\ 2Zuyderland Hospital, Clinic of Surgery, Tilburg, Netherlands
}

\section{HIIIIII| ABSTRACT}

\begin{abstract}
Aim: Stoma reversal in patients with concomitant abdominal wall defects can be cumbersome with the risk of many postoperative complications. Present study was conducted to evaluate feasibility and safety of single port restoration of left-sided colostomy in patients with concomitant incisional hernia.

Method: All patients with concomitant incisional hernia undergoing single-port reversal of left-sided colostomy (SPRLC) between 2012 and 2020 were included. Primary outcomes were surgical success rate and 30-day postoperative complication rate. Secondary outcome was subsequent hernia repair after successful stoma reversal.

Results: Twelve patients were included for analysis. Single-port reversal was possible in five patients, conversion to open surgery was needed in one patient and conversion to multiport laparoscopy in six patients. There was no postoperative mortality, reoperations or anastomotic leakages. Seven patients (58\%) encountered no postoperative complications, surgical site infection occurred in four patients, pneumonia in one patient. Median postoperative stay was 4 (range; 3-12) days. Two patients pursued hernia repair after successful stoma reversal.

Conclusion: SPRLC is feasible and can be considered as an attractive alternative to open approach in patients with a colostomy and concomitant incisional hernia. It can be considered as a step-wise approach for future abdominal wall repair.
\end{abstract}

Keywords: Single-port, hernia, ventral/surgery, incisional hernia, colostomy

\section{||l||l||l| ÖZ}

Amaç: Eşlik eden karın duvarı defektleri olan hastalarda stomanın tersine çevrilmesi, birçok postoperatif komplikasyon riski ile birlikte külfetli olabilir. Bu çalışma, eşlik eden kesi fitığı olan hastalarda sol taraflı kolostominin tek port restorasyonunun uygulanabilirliğini ve güvenliğini değerlendirmek için yapılmıştır.

Yöntem: Çalışmaya 2012 ve 2020 yılları arasında sol taraflı kolostominin tek portlu tersine çevrilmesi (SPRLC) uygulanan, kesi fitığı olan tüm hastalar dahil edildi. Birincil sonlanımlar; cerrahi başarı oranı ve 30 günlük postoperatif komplikasyon oranıydı. İkincil sonlanım, başarılı stoma tersine çevrilmesi ardından fitık onarımıdı.

Bulgular: Analize 12 hasta dahil edildi. Beş hastada tek portun tersine çevrilmesi mümkün oldu, 1 hastada açık cerrahiye ve 6 hastada çok portlu laparoskopiye geçiş gerekli oldu. Postoperatif mortalite, reoperasyon veya anastomoz kaçağı olmadı. Yedi hastada (\%58) postoperatif komplikasyon görülmedi, 4 hastada yüzeyel cerrahi alan enfeksiyonu, 1 hastada pnömoni meydana geldi. Ortalama postoperatif kalış süresi 4 (dağılım 3-12) gündü. İki hastada başarılı stoma tersine çevrilmesinden sonra fitık onarımı yapıldı.

Sonuç: SPRLC mümkündür ve kolostomi ile eşlik eden kesi fitığı olan hastalarda açık yaklaşıma iyi bir alternatif olarak düşünülebilir. Daha sonra yapılacak karın duvarı onarımı için adım adım bir yaklaşım olarak düşünülebilir.

Anahtar Kelimeler: Tek port, fitık, ventral/cerrahi, insizyonel fitık, kolostomi

Address for Correspondence/Yazışma Adresi: Yu Ting van Loon, MD,

Elisabeth-TweeSteden Hospital, Clinic of Surgery, Tilburg, Netherlands

E-mail: tinavanloon@gmail.com ORCID ID: orcid.org/0000-0002-9978-1091

回

${ }^{\circledR}$ Copyright 2021 by Turkish Society of Colon and Rectal Surgery

Turkish Journal of Colorectal Disease published by Galenos Publishing House. 


\section{Introduction}

Hartmann's procedure is often used for surgical emergencies of colorectal, gynaecological or vascular nature. ${ }^{1}$ Feared and common complications are superficial or deep site infections, wound dehiscence with subsequent laparostomy or incisional hernia, all resulting in significant morbidity and impaired quality of life. Repair of these hernias results in higher risk of postoperative complications due to the possibility of bacterial contamination. ${ }^{2,3}$ Classic or laparoscopic stoma reversal in patients with incisional hernias cannot be performed without extensive adhesiolysis, which can be cumbersome and harbours the risk of advertent or inadvertent enterotomies, potentially resulting in enterocutaneous fistulas. ${ }^{4,5}$ Moreover, possible contamination of prosthetic devices or dissection planes in case of mesh placement or component separation makes simultaneous abdominal wall reconstruction unattractive because of increased infectious risks. A combined procedure with stoma reversal and complex hernia repair can result in a higher risk of anastomotic leakage. ${ }^{6}$ These considerations led to a high threshold for stoma reversal in those patients.

Recently, a novel application of the single-port laparoscopy access system was described. By inserting this device in the abdominal fenestration of the colostomy, stoma reversal can be performed minimal invasively in a safe and controlled manner and achieves favourable outcomes. ${ }^{7,8}$ With this technique, adhesiolysis of the midline is unnecessary; therefore, the stoma can be reversed without extensive mobilisation or adhesiolysis and without simultaneous repair of the ventral hernia.

This study aimed to assess the feasibility and safety of single-port reversal of left-sided colostomy (SPRLC) in patients with concomitant incisional hernia. We postulate that SPRLC is feasible and safe in patients with a left-sided colostomy combined with a moderate to complex hernia.

\section{Method}

All consecutive patients who underwent SPRLC between November 2012 and March 2020 were assessed for inclusion in this study. During this period, all stoma procedures of end colostomies were performed with the single-port technique. All procedures were performed or supervised by experienced colorectal surgeons or consultants with extensive skills in laparoscopy and minimally invasive surgery.

The inclusion criteria for this study were patients with a left-sided colostomy and concomitant incisional abdominal wall hernia undergoing SPRLC. The exclusion criteria were single-port reversal of right-sided (ascending) colostomy or ileostomy procedures.
The operative procedures of the SPRLC were described in detail in a previous study. ${ }^{7}$ Briefly, the colostomy was mobilised beyond the fascia into the abdomen, and the anvil for the CDH29 circular stapler (Ethicon Endo-Surgery, Cincinnati, OH, USA) was placed in the descending colon before returning it to the abdominal cavity through the original colostomy site. A pneumoperitoneum was established after placement of the GelPOINT Path Access Platform (Applied Medical, Los Angeles, CA, USA). Where necessary, the splenic flexure or transverse colon was mobilised, and adhesiolysis was performed under direct vision. Continuity was restored after adhesiolysis and proper visualisation of the rectal stump with the use of the

CDH29 circular stapler. All wounds were closed intracutaneously.

All patients were treated following the enhanced recovery after surgery protocol. Patients were discharged from the hospital when they were able to tolerate normal food, pass stool, were able to mobilise similar to preoperative levels of mobilisation and had adequate control of pain with use of oral analgesia. The minimum follow-up period was 30 days postoperatively.

Patient characteristics (including sex, age and body mass index), index surgery characteristics (such as reason for surgery and initial postoperative complications) and surgical details (i.e. time interval between index surgery and SPRLC, duration of SPRLC and conversion) were collected using the electronic patient database.

Primary outcomes were surgical success rate, which was defined as technical success rate of the single-port approach for stoma reversal and 30-day postoperative complication rate. Postoperative complication was defined as infections [such as surgical site infection (SSI) and intra-abdominal abscess], urogenital complications (such as urinary tract infection and urine retention), ileus or gastroparesis, pulmonary complications (such as pneumonia and exacerbation of chronic obstructive pulmonary disease) and blood-related complications (such as rectal blood loss, thrombosis or haematoma in wound or bleeding from an anastomosis). In this study, anastomotic leakage, re-interventions under local or general anaesthesia and intensive care unit (ICU) admission were considered major complications. The secondary outcome was subsequent hernia repair after SPRLC.

All patients gave informed consent during outpatient clinic counselling for SPRLC. Approval of the institutional review board or ethics committee was not required because of the observational nature of this study. This report was prepared in concordance with the STROBE guidelines (http://www. equator-network.org/reporting-guidelines/strobe/). 


\section{Results}

A total of 105 patients underwent single-port reversal of continuity in Elisabeth-TweeSteden Hospital, Tilburg, Netherlands. Of these patients, 93 did not meet the inclusion criteria (Figure 1). Twelve patients were included in this study, including 7 men and 5 women with a median age of 60.9 (range; 27.6-76.9) years, median body mass index of 29.0 (range; 22.7-61.1) $\mathrm{kg} / \mathrm{m}^{2}$ and median and mean abdominal wall defect of 120 and 173.6 (range; 49450) $\mathrm{cm}^{2}$, respectively. Most common indications for index surgery were complicated diverticulitis and malignancy. The mean time between the index surgery and SPRLC was approximately 2 years, and the median time was 536 (range; 190-2384) days. An overview of patient characteristics and surgical and postoperative outcomes can be found in Tables 1 and 2 .

\section{Surgical Details}

Of the 12 procedures, $42 \%(n=5)$ were technically successful by solely using the single-port approach. Six patients needed additional placement of one or two 5-mm trocar.

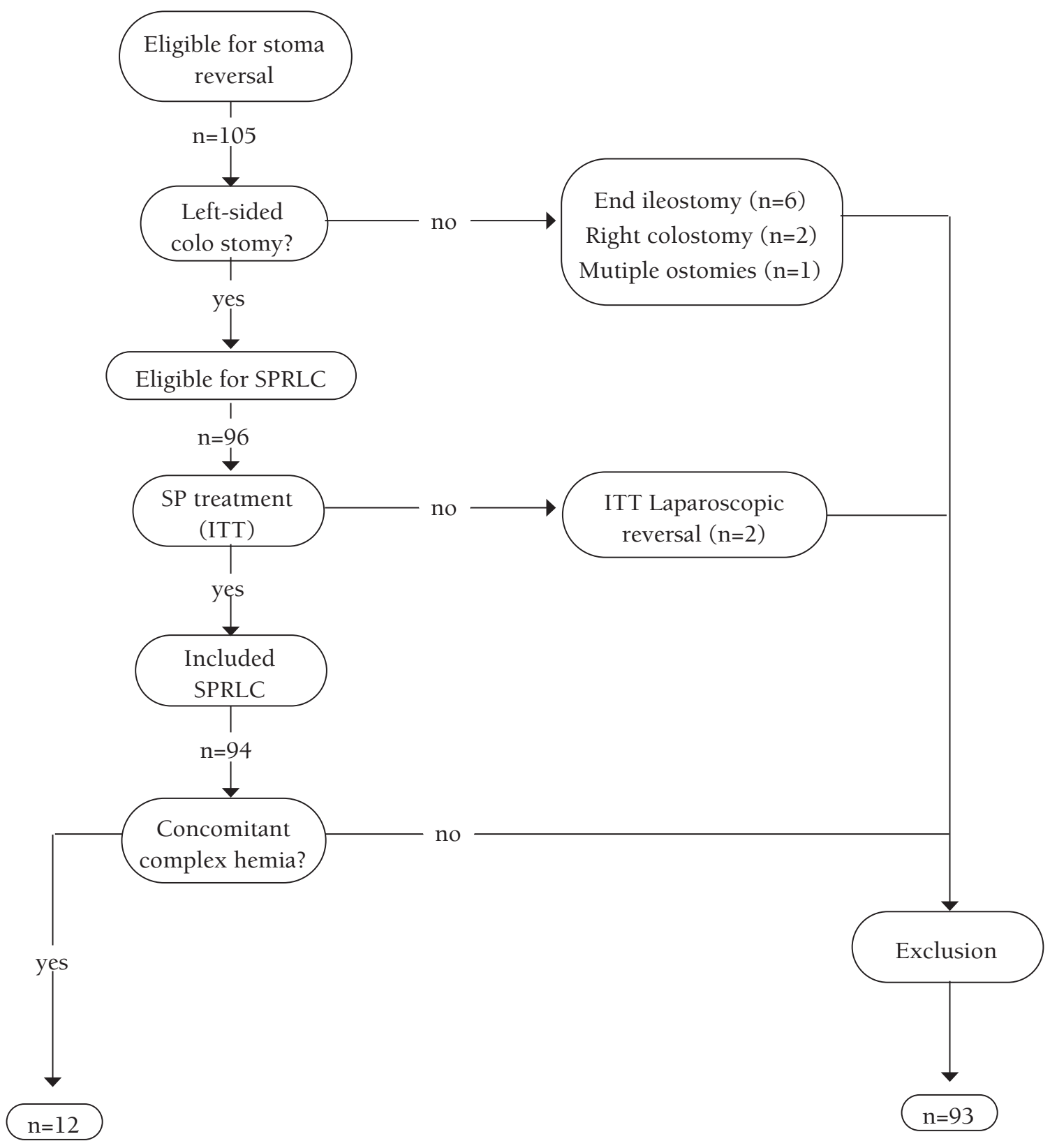

Figure 1. Flow chart of patient inclusion 
Reasons for the additional trocar placement were needed for extensive laparoscopic adhesiolysis $(\mathrm{n}=5)$, mobilisation of the splenic flexure $(\mathrm{n}=1)$ or suture reinforcement of the anastomosis after positive air leak testing $(\mathrm{n}=1)$. Conversion to open midline laparotomy was needed in one patient because of iatrogenic injury to adhesive small bowel during placement of the single-port device. All procedures were technically successful in restoring intestinal continuity.
The mean duration of operation was 137 (range; 85-197) min, and the duration of operation was not recorded in one patient. Figure 2 presents images of the abdomen before and after SPRLC.

\section{Postoperative Results}

No 30-day postoperative mortality, reoperations or anastomotic leakage was recorded in these patients. Moreover, seven (58.3\%) patients did not have postoperative

Table 1. Patient characteristics

\begin{tabular}{|c|c|c|c|c|c|c|c|c|}
\hline Number & $\begin{array}{l}\text { Sex } \\
(M / F)\end{array}$ & $\begin{array}{l}\text { BMI } \\
\left(\mathrm{kg} / \mathrm{m}^{2}\right)\end{array}$ & $\begin{array}{l}\text { Age* }^{*} \\
\text { (years) }\end{array}$ & $\begin{array}{l}\text { ASA } \\
\text { class }\end{array}$ & $\begin{array}{l}\text { Indication and type } \\
\text { of index surgery }\end{array}$ & $\begin{array}{l}\text { Year of } \\
\text { index } \\
\text { surgery }\end{array}$ & $\begin{array}{l}\text { Adverse events in initial } \\
\text { postoperative course }\end{array}$ & $\begin{array}{l}\text { Dimensions } \\
\text { abdominal wall } \\
\text { defect }^{@}\end{array}$ \\
\hline 1 & $\mathrm{~F}$ & 26.3 & 66.0 & 3 & $\begin{array}{l}\text { Malignancy, open } \\
\text { left hemicolectomy }\end{array}$ & 2012 & $\begin{array}{l}\text { Relaparotomy for } \\
\text { anastomotic leakage }\end{array}$ & $7 \times 7 \mathrm{~cm}^{\#}$ \\
\hline 2 & $\mathrm{~F}$ & 61.1 & 47.3 & 3 & $\begin{array}{l}\text { Complicated } \\
\text { diverticulitis, open } \\
\text { sigmoidectomy }\end{array}$ & 2012 & $\begin{array}{l}\text { Relaparotomy for } \\
\text { anastomotic leakage, } \\
\text { superficial and deep SSI }\end{array}$ & 30x15 cm ${ }^{@}$ \\
\hline 3 & $\mathrm{~F}$ & 25.1 & 61.1 & 3 & $\begin{array}{l}\text { Complicated } \\
\text { diverticulitis, open } \\
\text { sigmoidectomy }\end{array}$ & 2013 & $\begin{array}{l}\text { Multiple relaparotomies } \\
\text { for wound dehiscence }\end{array}$ & $18 \times 13 \mathrm{~cm}^{\#}$ \\
\hline 4 & $\mathrm{M}$ & 24.8 & 65.6 & 1 & $\begin{array}{l}\text { Sigmoid volvulus, } \\
\text { converted } \\
\text { sigmoidectomy }\end{array}$ & 2015 & $\begin{array}{l}\text { Relaparotomy for } \\
\text { anastomotic leakage, } \\
\text { superficial and deep SSI }\end{array}$ & $15 \times 8 \mathrm{~cm}^{\#}$ \\
\hline 5 & M & 30.2 & 61.8 & 3 & $\begin{array}{l}\text { Complicated } \\
\text { diverticulitis, } \\
\text { open Hartmann's } \\
\text { procedure }\end{array}$ & 2015 & Superficial SSI & $10 \times 10 \mathrm{~cm}^{\#}$ \\
\hline 6 & M & 22.7 & 76.9 & 2 & $\begin{array}{l}\text { Complicated } \\
\text { diverticulitis, open } \\
\text { sigmoidectomy }\end{array}$ & 2013 & $\begin{array}{l}\text { Relaparotomy for } \\
\text { anastomotic leakage, } \\
\text { superficial and deep SSI }\end{array}$ & $8 \times 15 \mathrm{~cm}^{\#}$ \\
\hline 7 & M & 32.9 & 59.3 & 3 & $\begin{array}{l}\text { Endovascular aortic } \\
\text { aneurysm repair }\end{array}$ & 2015 & $\begin{array}{l}\text { Laparotomy for sigmoid } \\
\text { ischaemia, superficial SSI }\end{array}$ & 20x17 cm \\
\hline 8 & $\mathrm{~F}$ & 30.5 & 72.4 & 2 & $\begin{array}{l}\text { Complicated } \\
\text { diverticulitis, } \\
\text { laparoscopic } \\
\text { sigmoidectomy }\end{array}$ & 2018 & $\begin{array}{l}\text { Laparotomy for } \\
\text { anastomotic leakage, } \\
\text { superficial and deep SSI }\end{array}$ & 18x15 cm ${ }^{@}$ \\
\hline 9 & M & 31.5 & 56.3 & 2 & $\begin{array}{l}\text { Malignancy, } \\
\text { converted left } \\
\text { hemicolectomy with } \\
\text { stoma }\end{array}$ & 2013 & Superficial SSI & 11x10 cm ${ }^{@}$ \\
\hline 10 & $\mathrm{~F}$ & 27.8 & 60.8 & 2 & $\begin{array}{l}\text { Malignancy, open } \\
\text { left hemicolecomy } \\
\text { with stoma }\end{array}$ & 2016 & $\begin{array}{l}\text { Relaparotomy for stoma } \\
\text { revision }\end{array}$ & $7 \times 7 \mathrm{~cm}^{@}$ \\
\hline 11 & M & 32.1 & 27.6 & 1 & $\begin{array}{l}\text { Complicated } \\
\text { diverticulitis, } \\
\text { laparoscopic lavage }\end{array}$ & 2014 & $\begin{array}{l}\text { Relaparotomy for } \\
\text { Hartmann's procedure }\end{array}$ & $7 \times 7 \mathrm{~cm}^{@}$ \\
\hline 12 & M & 27.8 & 62.2 & 1 & $\begin{array}{l}\text { Open iliac aneurysm } \\
\text { repair }\end{array}$ & 2012 & $\begin{array}{l}\text { Relaparotomies for } \\
\text { thrombectomy and } \\
\text { sigmoid ischaemia, } \\
\text { superficial SSI }\end{array}$ & $16 \times 12$ cm ${ }^{@}$ \\
\hline
\end{tabular}

*Age at the time of the single-port left-sided colostomy reversal, ${ }^{\circledR}$ Defect measured using CAT scans,

"Defect measured during physical examination, BMI: Body mass index, ASA class: American Society of Anesthesiologists classification, SSI: Surgical site infection 
complications within 30 days after surgery, and five patients developed one postoperative complication. Four (33.3\%) patients developed an SSI of the old stoma fenestration; all were treated conservatively by removing the sutures and applying regular wound dressings. One patient experienced a major complication and needed ICU observation due to postoperative pneumonia and recovered without other postoperative adverse events. The median postoperative stay was 4.0 (range; 2-16) days.

\section{Hernia Repair}

Two patients underwent abdominal wall reconstruction due to persisting symptoms of incisional hernias after recovery from SPRLC. One patient died of peritoneal metastases while considering hernia repair. Most other patients $(n=7)$ reported satisfaction with their abdominal condition and life following SPRLC. Two patients without symptoms of their hernia expressed their wish to pursue abdominal wall repair for purely cosmetic reasons and therefore withheld from surgery. They declined abdominal wall reconstruction after counselling and shared decision making.

\section{Discussion}

This study shows that SPRLC is a feasible, safe and effective technique for stoma reversal in patients with a left-sided colostomy and a concomitant incisional hernia. The median length of stay was short with 4 (range; 2-16) days, and there was no anastomotic leakage or need for reoperations or re-interventions. The postoperative complication rate was acceptable. Postoperative pneumonia was the only major complication in this study, which was considered inherent to intra-abdominal operations and not specifically linked to the use of the single-port approach. We believe that

Table 2. Surgical and postoperative outcomes

\begin{tabular}{|c|c|c|c|c|c|c|c|c|c|c|c|}
\hline Number & $\begin{array}{l}\text { Sex } \\
(M / F)\end{array}$ & $\begin{array}{l}\text { Age at } \\
\text { SPRLC }\end{array}$ & $\begin{array}{l}\text { Year } \\
\text { SPRLC }\end{array}$ & $\begin{array}{l}\text { Days } \\
\text { until } \\
\text { SPRLC }\end{array}$ & $\begin{array}{l}\text { Surgical } \\
\text { time } \\
\text { (min) }\end{array}$ & $\begin{array}{l}\text { Extra } \\
5 \mathrm{~mm} \\
\text { trocar }\end{array}$ & $\begin{array}{l}\text { Reason for } \\
\text { extra trocar } \\
\text { placement }\end{array}$ & $\begin{array}{l}\text { LOS } \\
\text { (days) }\end{array}$ & $\begin{array}{l}\text { Postoperative } \\
\text { complication }\end{array}$ & $\begin{array}{l}\text { Calvien- } \\
\text { Dindo } \\
\text { classificatioin }\end{array}$ & $\begin{array}{l}\text { Hernia } \\
\text { repair } \\
\text { after } \\
\text { SPRLC }\end{array}$ \\
\hline 1 & $\mathrm{~F}$ & 66.0 & 2014 & 760 & 85 & 1 & $\begin{array}{l}\text { Mobilisation } \\
\text { splenic } \\
\text { flexure }\end{array}$ & 12 & Pneumonia & 4 & No \\
\hline 2 & $\mathrm{~F}$ & 47.3 & 2015 & 1193 & 91 & 1 & $\begin{array}{l}\text { Extensive } \\
\text { adhesiolysis }\end{array}$ & 4 & $\begin{array}{l}\text { Superficial SSI } \\
\text { (stoma wound) }\end{array}$ & 1 & Yes \\
\hline 3 & $\mathrm{~F}$ & 61.1 & 2017 & 1294 & 133 & 1 & $\begin{array}{l}\text { Extensive } \\
\text { adhesiolysis, } \\
\text { anastomosis } \\
\text { suture } \\
\text { reinforcement }\end{array}$ & 5 & No & - & No \\
\hline 4 & M & 65.6 & 2016 & 481 & 128 & 0 & - & 3 & $\begin{array}{l}\text { Superficial SSI } \\
\text { (stoma wound) }\end{array}$ & 1 & No \\
\hline 5 & M & 61.8 & 2015 & 246 & 128 & 0 & - & 2 & No & - & No \\
\hline 6 & M & 76.9 & 2014 & 255 & - & 0 & - & 5 & No & - & No \\
\hline 7 & M & 59.3 & 2017 & 706 & 115 & 1 & $\begin{array}{l}\text { Extensive } \\
\text { adhesiolysis, } \\
\text { aiding } \\
\text { visibility small } \\
\text { pelvis }\end{array}$ & 4 & No & - & No \\
\hline 8 & $\mathrm{~F}$ & 72.4 & 2019 & 359 & 163 & 1 & $\begin{array}{l}\text { Extensive } \\
\text { adhesiolysis }\end{array}$ & 3 & No & - & No \\
\hline 9 & M & 56.3 & 2015 & 591 & 174 & $*$ & - & 5 & $\begin{array}{l}\text { Superficial SSI } \\
\text { (both wounds) }\end{array}$ & 1 & No \\
\hline 10 & $\mathrm{~F}$ & 60.9 & 2017 & 331 & 197 & 0 & & 3 & No & - & No \\
\hline 11 & M & 27.6 & 2015 & 190 & 149 & 0 & & 3 & $\begin{array}{l}\text { Superficial SSI } \\
\text { (stoma wound) }\end{array}$ & 1 & No \\
\hline 12 & M & 56.9 & 2014 & 508 & 148 & 2 & $\begin{array}{l}\text { Extensive } \\
\text { adhesiolysis }\end{array}$ & 3 & No & - & Yes \\
\hline
\end{tabular}


the minimally invasive characteristics of these procedures resulted in the short postoperative length of stay and low postoperative morbidity. To the best of our knowledge, this is the first study that evaluates the single-port approach in reversing left-sided colostomy in patients with concomitant incisional hernia.

Upon reviewing available literature, the postoperative complication rates of reversal of left-sided colostomies vary between $3 \%$ and $50 \%{ }^{4,9,10}$, and the most common complication is SSI in over $25 \%$ of the patients. ${ }^{11}$ Although no differences were found in the postoperative mortality after laparoscopic or open reversal of left-sided colostomy (which can be up to 5\%), the laparoscopic approach results

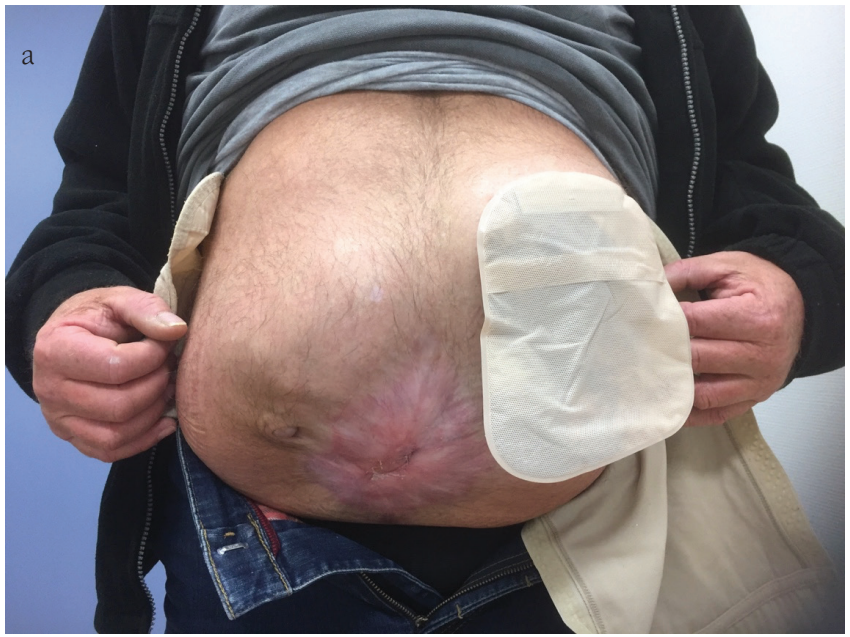

b

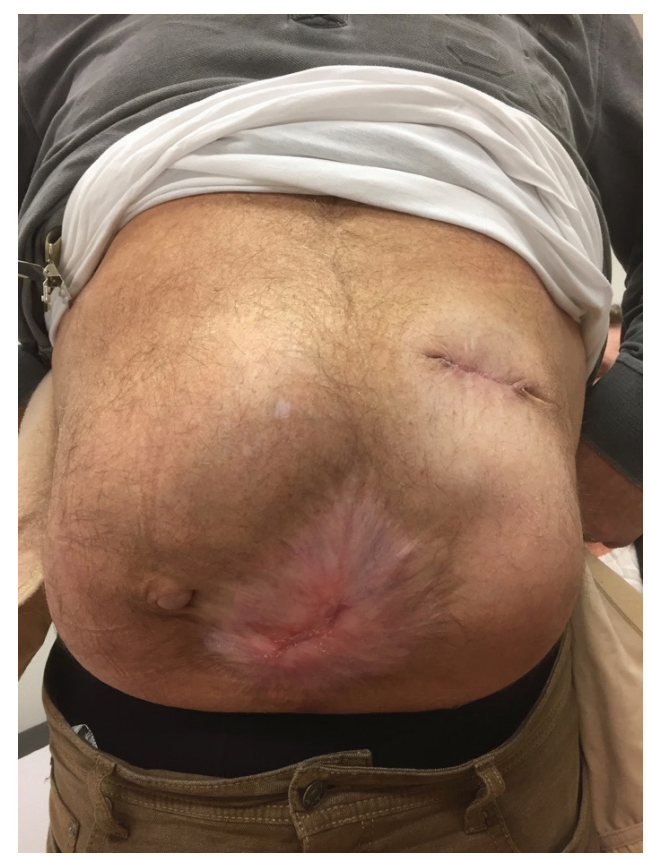

Figure 2. a) Picture of a patient with a left-sided colostomy and complex hernia before SPRLC, b) Picture of the same patient after SPRLC

SPRLC: Single-port reversal of left-sided colostomy in lower postoperative minor and major complications such as SSI, cardiopulmonary complications, anastomotic leakage and need for reoperations. ${ }^{11}$ Furthermore, it is important to appreciate the difference in the severity of SSI of the former stoma fenestration, which is relatively small compared with SSI of a laparotomy wound. Moreover, SSI of a laparotomy wound in the presence of prosthetic devices or after component separation can have catastrophic results.

Complex hernias have great influence on the perceived quality of life of the patients. ${ }^{12}$ However, no investigations have shown whether the presence of a hernia, presence of a stoma or combination of the two is most bothersome. Many patients pursue repair; however, because of the high rates of postoperative morbidity, most surgeons are hesitant to offer restorative surgery. We found a surprising low rate of subsequent hernia repair after SPRLC in two patients, so far. This may suggest that patients suffer more from the presence of the colostomy (albeit combined with the hernia) than from the hernia per se. This may be an interesting avenue for further research.

Complex hernias are challenging and difficult to repairthe optimal reconstructive strategy remains unclear. ${ }^{13}$ Some studies have shown that concomitant stoma reversal with hernia repair can result in unacceptable high rates of postoperative morbidity and increased length of hospital stay compared with patients without stoma reversal., ${ }^{6,13}$ Either mesh infection or refraining from mesh enhancement might lead to higher recurrence rates and postoperative complications than the two separate procedures. After successful stoma reversal, the abdominal wall can be restored with optimal mesh reinforcement without possible risk of contamination. Therefore, single-staged reversal of the complex hernia and stoma reversal might not be advised as primary choice of treatment.

We postulate that by using the single-port approach, stoma reversal is possible without dissection of the midline and therefore without the need to repair the incisional hernia during the same procedure. SPRLC results in lesser adhesiolysis and shorter duration of the procedures and thus reducing the patients' surgical trauma. All these factors lower the rates of postoperative morbidity when compared with conventional open procedures. ${ }^{7,8}$ After successful restoration of continuity, the patient can subsequently choose whether additional reconstruction of the abdominal wall is desirable, without the additional risk of the presence of the stoma or stoma reversal.

\section{Study Limitations}

The small number of patients in this study is a major limitation, and we were unable to compare our results with those of open stoma reversal procedures in patients with 
incisional hernia, which was also due to the very specific characteristics of this small subgroup of patients. In our opinion, open stoma reversal with or without hernia repair is not desirable and is not our primary approach. Our experience with open stoma reversal with concomitant repair of incisional hernia is therefore limited.

This new technique shows favourable results in postoperative complication rate and length of stay, thus lowering our threshold to offer this approach in our patients with a stoma combined with abdominal wall defects. We believe that the single-port approach is a feasible and effective solution for stoma reversal in patients with left-sided end colostomy with a complex hernia. SPRLC could be a part of the staged treatment for patients with incisional hernia and colostomy and could be safely offered and performed by colorectal surgeons with sufficient laparoscopic experience. Further research is necessary to evaluate the results in a larger cohort and to evaluate the applicability of this technique for the reversal of other types of stomas.

\section{Conclusion}

The SPRLC is feasible and can be considered a serious and attractive alternative to an open approach in patients with a left-sided end colostomy and concomitant incisional hernia. It shows promising results in terms of postoperative complication rate and length of stay and can be safely offered and performed by surgeons with sufficient laparoscopic experience.

\section{Ethics}

Ethics Committee Approval: Retrospective study.

Informed Consent: Obtained.

Peer-review: Externally and internally peer reviewed.

\section{Authorship Contributions}

Surgical and Medical Practices: Y.T.L., S.C., D.K.W., J.H., D.Z., Concept: Y.T.L., S.C., D.K.W., J.H., D.Z., Design: Y.T.L., S.C., D.K.W., J.H., D.Z., Data Collection or Processing: Y.T.L., S.C., D.K.W., J.H., D.Z., Analysis or Interpretation: Y.T.L., S.C., D.K.W., J.H., D.Z., Literature Search: Y.T.L., S.C., D.K.W., J.H., D.Z., Writing: Y.T.L., S.C., D.K.W., J.H., D.Z.
Conflict of Interest: No conflict of interest was declared by the authors.

Financial Disclosure: The authors declared that this study received no financial support.

\section{References}

1. Barbieux J, Plumereau F, Hamy A. Current indications for the Hartmann procedure. J Visc Surg 2016;153:31-38

2. Slater NJ, Montgomery A, Berrevoet F, Carbonell AM, Chang A, Franklin M, Kercher KW, Lammers BJ, Parra-Davilla E, Roll S, Towfigh S, van Geffen E, Conze J, van Goor H. Criteria for definition of a complex abdominal wall hernia. Hernia 2014;18:7-17.

3. Kanters AE, Krpata DM, Blatnik JA, Novitsky YM, Rosen MJ. Modified hernia grading scale to stratify surgical site occurrence after open ventral hernia repairs. J Am Coll Surg 2012;215:787-793.

4. Toro A, Ardiri A, Mannino M, Politi A, Di Stefano A, Aftab Z, Abdelaal A, Arcerito MC, Cavallaro A, Cavallaro M, Bertino G, Carlo I. Laparoscopic reversal of hartmann's procedure: state of the art 20 years after the first reported case. Gastroenterol Res Pract 2014;2014:530140.

5. Lucchetta A, De Manzini N. Laparoscopic reversal of Hartmann procedure: is it safe and feasible? Updates Surg 2016;68:105-110.

6. Baastrup NN, Hartwig MFS, Krarup PM, Jorgensen LN, Jensen KK. Anastomotic leakage after stoma reversal combined with incisional hernia repair. World J Surg 2019;43:988-997.

7. Clermonts SH, de Ruijter WM, van Loon YT, Y-TT, Wasowicz DK, Heisterkamp J, Maring JK, Zimmerman DDE. Reversal of Hartmann's procedure utilizing single-port laparoscopy: an attractive alternative to laparotomy. Surg Endosc 2016;30:1894-1901.

8. van Loon YT, Clermonts S, Wasowicz DK, Zimmerman DDE. Reversal of left-sided colostomy utilizing single-port laparoscopy: single-center consolidation of a new technique. Surg Endosc. 2020;34:332-338.

9. van de Wall BJ, Draaisma WA, Schouten ES, Broeders IAMJ, Consten ECJ. Conventional and laparoscopic reversal of the Hartmann procedure: a review of literature. J Gastrointest Surg 2010;14:743-752.

10. Horesh N, Rudnicki Y, Dreznik Y, Zbar AP, Gutman M, Zmora O, Rosin D. Reversal of Hartmann's procedure: still a complicated operation. Tech Coloproctol 2018;22:81-87.

11. Roig JV, Cantos M, Balciscueta Z, Uribe N, Espinosa J, Roselló V, García-Calvo R, Hernandis J, Landete F, Sociedad Valenciana de Cirugía Cooperative Group. Hartmann's operation: how often is it reversed and at what cost? A multicentre study. Colorectal Dis 2011;13:e396-e402.

12. van Ramshorst GH, Eker HH, Hop WC, Lange JF. Impact of incisional hernia on health-related quality of life and body image: a prospective cohort study. Am J Surg 2012;204:144-150.

13. Mericli AF, Garvey PB, Giordano S, et al. Abdominal Wall Reconstruction with Concomitant Ostomy-Associated Hernia Repair: Outcomes and Propensity Score Analysis. J Am Coll Surg. 2017;224:351-61 e2. 